\title{
Occupational Stress and Level of Performance among Staff Nurses at Belkas Central Hospital
}

\author{
${ }^{1}$ Dr .Safaa Abd El-Moneim Tawfiqu Zahran; ${ }^{2}$ Dr .Abeer Elsayed Mohammed \\ Berma; ${ }^{3}$ Karima Abd El-Sayed Mohammed Abu El-enin \\ ${ }^{1}$ Assistant Professor of Nursing Administration, Faculty of Nursing, Tanta University \\ ${ }^{2}$ Lecturer of Psychiatric Nursing and Mental Health,, Faculty of Nursing, Port-Said \\ University ; ${ }^{3}$ B.Sc Nursing), Zagazig University
}

\begin{abstract}
Background: Occupational stress has consequences on both the individual and the organization which affects staff nurses' performance. Aim: This study was to study the relationship between occupational stress and level of staff nurses performance at Belkas Central Hospital affiliated to Ministry of Health.design: A correlational descriptive research design was followed in this study. Subjects:The subjects of the study compromised 131 staff nurses in Emergency Department, Dialysis Neonatal Unit and Intensive Care Units at Belkas Central Hospital. Method-Two tools were used for data collection؛ the first tool: occupational stress questionnaire to assess their occupational stress level, in addition to socio-demographic characteristics of staff nurses. The second tool was observational checklist to assess staff nurses practice. Results: The study revealed that, staff nurses suffering from high level of occupational stress but their performance were satisfactory. Also there were no statistically significant correlation between staff nurses performance and their stress level. Conclusion and Recommendations: Although most of staff nurses had high level of occupational stress, they also had satisfactory score of performance. Thus, the study recommended that occupational stress should be managed through staff nurses participation in decision making, controlling interruptions rorganizing work environment and provide staff nurses with training programs to improve their performance and their ability to cope with stress.
\end{abstract}

Keywords: Nurses performance, Occupational stress, performance appraisal . 


\section{INTRODUCTION}

Workers are exposed to different situations that can lead to stress; nursing job specifically have several kinds of stress, will not be found in other non-health sectors (Ugur et al., 2007). This is because nurses in their daily basis practices are exposed to life and death situations, workload, long working hours in different shifts, competition, insufficient knowledge and information sharing with peers, physicians (Milutinovic et al., 2012). Stress is a common experience that is part of every one's life. It can be good for a person. Good stress, called eustress that help a person to complete a report on time or generate a good, quick problem solving procedure (Ivancevich, 2003).

Stress always related to imbalance between demands made on us from external sources and capabilities to meet those demands which usually lead to physical, physiological consequences (Kaur, 2009). Stress was defined conceptually as the physical, chemical, and emotional process that produces tension and can cause illness. Stress can be perceived as either positive or negative although stress is generally considered to be negative. There are many events that can be the cause of negative stress for some individuals and positive stress for others. In other words, not all individuals are stressed by the same situation (Richard, 2006).

Nursing plays a dominant role in the determination of overall patient satisfaction with healthcare (Clark et al., 2007). Performance of employees is essential in accomplishing the goals and objectives of an organization (Sansgiry, 2006). Abu Al Rub \& Al-Zara (2008) defined job performance as the overall effectiveness of the person in carrying out his or her roles and responsibilities related to direct patient care. Charles (2006) viewed performance as something a person or organization does (process, procedure) or achieves (outcomes).

Walshe \& Smith (2011) found that performance was determined by two elements: ability and motivation. Ability is made up of a collection of physical and mental capacities that enable a person to exhibit a skill or set of skills. Thus ability is an innate capacities that is molded by experience and training. Motivation is willingness to work and a desire to achieve. Motivation influences the vigor and diligence with which an individual applies his or her capability to do a task. The performance of health organization depends on the knowledge, skills and motivation of employees. It 
is therefore important for employers to provide suitable working conditions to ensure that performance of employees meet the desired standards (Awases, 2006).

Ismail et al. (2015) found that examining the effects of nursing tasks and their physiological and psychological demands on distress and job performance in real nursing time will inform theoretical understanding of nurse stress and its determinants which will reduce nurse distress, improve patient care, and develop improved methods of investigating work-related stress, retention, and patient care.

\section{Significance of the study:}

Occupational stress can cause a lot of problems which take your focus away from your performance to other time and places that will negatively affect nurses' level of performance. Job performance can help to determine how effectively the staff nurses can carry out their roles and responsibilities related to their job.

\section{AIM OF STUDY :}

The aim of this study was to assess the relationship between level of occupational stress and level of staff nurses performance at Belkas Central Hospital.

\section{Research questions:}

1- What is the level of occupational stress among staff nurses in Belkas Central Hospital?

2- What is the level of performance among staff nurses in Belkas Central Hospital?

3- Is there a relationship between level of occupational stress and level of performance among nurses in Belkas Central Hospital?

\section{SUBJECTS AND METHOD :}

\section{Research design}

A correlational descriptive design was utilized in this study.

\section{Study setting:}

This study was carried out at Belkas Central Hospital which affiliated to the Ministry of Health - Dakahlia Governorate at emergency Department, Dialysis Unit, Neonatal Intensive Care Unit and Intensive Care Unit. 


\section{Study subjects:}

The study sample was comprised from all staff nurses working at the previously mentioned setting who were willing to participate in the study and have experience not less than six months. The total numbers of staff nurses were 131 nurses (41from emergency department, 34 from dialysis unit, 30 from neonatal intensive care unit and 26 from intensive care unit).

\section{Tools of data collection:-}

\section{TOOL I: Occupational stress Questionnaire:}

it consists of two parts:

Part (1): Socio-demographic part: it was developed by the researcher to elicit data about staff nurses as age, gender, years of experience, number of children, educational level, place of employment and duration of experience.

Part (2): Occupational stress scale: Occupational Stress Scale was developed by (Abdelrazek, 2000) and based on literature review of Holmes \& Rahe' (1967), to assess the occupational stress among staff nurses. It contains 52 questions It was divided into six subdivisions:-

1) Role stressors that included fourteen questions.

2) Task stressors included seven questions.

3) Patient stressors included four questions.

4) Physician stressors included seven questions.

5) Human and physical resource stressors included eleven questions.

6) Educational/vocational stressors included nine questions.

\section{The scoring system:}

The score of each area of major factors contributing to stress was gained by summing the marks given for its statement, then its percentage were calculated through the following formula:

Score given to nurses for each area $\mathrm{x} 100=$ Score percentage $\%$

Total score of each area 
The scale was rated into three levels as follows: high, moderate and low and scored as 3,2 , and 1 respectively. It was categorized as the following; high occupational stress level (more than $66.67 \%$ of responses), moderate occupational stress level $(33.33 \%$ $66.67 \%$ of responses) and low occupational stress level (less than $33.33 \%$ of responses) (Abdelrazek, 2000).

\section{Tool ll: Performance observation checklist:}

Observational checklist which developed by (Haussaman, 1997; Said, 2000) and modified by the researcher. It was used to assess level of performance among staff nurses. It was divided into five subscales which contain 51 items:-

1. Assessment of patient status (6 items).

2. General patient care which contain four subscales which are :

- Maintain safe and comfortable environment (5 items).

- Dressing (5 items).

- Vital signs (2 items).

- Medication (3 items).

3. Communication (8 items).

4. Patients' psychosocial aspects (12 items).

5. Professionalism which contain three subscales which are:

- Good relationship with health team members (4 items).

- Keep good general appearance (4 items).

- Physical presence (2 items).

\section{The scoring system:}

At performance observation checklist the observed items were checked as done, partially done, not done and not applicable for each activity and scored as 3, 2, 1, and 0 respectively. Consequently this observation repeated at three times in different shifts.

Total performance score was also calculated by dividing individual total score by the maximum possible score. Then the average of the three shifts was calculated for each nurse and this average considered as the level of performance. It was categorized as satisfactory level (65\% or more) and unsatisfactory level (less than 65\%). 


\section{Operational Design:}

Operational design includes the preparatory phase, content validity, reliability, the pilot study ethical consideration and the field work.

\section{Preparatory phase:}

Preparation of tools of data collection was done during this phase after extensive literature review by using books, articles, internet and periodicals magazines to select suitable tools for data collection.

\section{Validity:}

The tools of data collection were reviewed by a panel of five nursing experts in the field of nursing administration and psychiatric nursing. Testing validity of the proposed tools using face and content validity.

\section{Reliability:}

Alpha cronbach's test was used to measure consistency of occupational stress tool and performance observational checklist tool, alpha $=0.83$ and 0.77 respectively.

\section{Pilot study:}

Before performing the actual study, a pilot study was carried out on $10 \%$ of staff nurses working in the selected units at Belkas Central Hospital. The pilot study was done to assess the applicability of the tools and to estimate the proper time required for answering the questionnaire, needed time for data collection, and feasibility of conducting the research. The sample that used for pilot study were 14 staff nurses, it excluded from the sample.

\section{Ethical considerations :}

Before conduction of the study,

Staff nurses under study were assured about the confidentiality of the information gathered and that it was used only for the purpose of the study.

Staff nurses who included in the study were informed about their right to refuse or withdraw at any time.

\section{Field work:}

To carry out the study; an approval was obtained from hospital director and nursing directors of the whole hospital and the selected departments (emergency, dialysis, 
neonates and intensive care unit). A letter was issued to them from the Faculty of Nursing - Port Said University explaining the aim of the study in order to obtain permission and cooperation to conduct the study.

Data collection was taking about nine months (start at the beginning of September 2013 and was completed by the end of May 2014). The researcher observed each staff nurse in three different shifts according to their work. First, the researcher interviewed the nurses and explained the purpose of the study. The questionnaire sheet was distributed and took at the same shift while the researcher stay with them in the unit for observing their performance after staff nurse fulfilling it. Then, the researcher filled the observational checklist during the actual nursing work.

\section{Administrative design:-}

The necessary official letters to carry out the study were issued from the faculty of nursing at Port Said University to the directors of Belkas Central Hospital, permission were also secured from the head nurses of the units under study. Additionally, an oral consent was taken from each nurse after explaining the aim of the study to them to attain their cooperation.

\section{Statistical design:}

The collected data were organized, tabulated and statistically analyzed using statistical package for social sciences (SPSS) version 20. Number and present distribution of the studied data for each nurse were calculated, description of variables as mean, SD and range were also used. Statistical significance was considered at $\mathrm{P}<0.05$.

\section{RESULTS:}

The study results revealed that most of staff nurses (96.9\%) were female, the highest percentage of them (80.9\%) ranges from 20 to 30 years old and more than half of staff nurses $(56.5 \%)$ have experienced less than 5 years of experience.

Table (1): Shows the staff nurses level of occupational stress at Belkas Central Hospital. It reveals that staff nurses generally had high stress level. It illustrated that the educational and vocational stressors were represents the highest area of 
occupational stress on nurses $(93.1 \%)$, followed by physician stressors $(87.8 \%)$, then human and physical resources stressors (79.4\%).

Table (2): Shows the staff nurses performance at Belkas Central Hospital. It reveals that the majority of nurses $(97.7 \%)$ have satisfactory performance in general patient care, followed by $95.4 \%$ of them had satisfactory performance in professionalism. Also, the figure illustrated that more than half of staff nurses $(57.3 \%)$ had unsatisfactory performance level in patients' psychosocial aspects.

Table (3): Shows correlation between staff nurses stressors and their performance score at Belkas Central Hospital. It reveals that there are statistically significant correlation between total staff nurses stressors and their performance score. Also, the table illustrated that there are statistically significant correlation present with all staff nurses stressors and their performance except task stressors (0.069) and human and physical stressors (0.098).

Table (4): Shows the relationship between staff nurses' occupational stress level and their demographic characteristics at Belkas Central Hospital. There were statistically significant correlation between staff nurses level of stress and marital status, number of children, then age and educational level. There were no statistically significant correlation between staff nurses level of stress and type of department (0.098) and their years of experience $(0.110)$.

Table (5): Shows the relationship between staff nurses' performance level and their demographic characteristics at Belkas Central Hospital. It reveals that there are significant relation between staff nurses performance and their demographic characteristics that present in all characteristics except their number of children $(0.82)$ and years of staff nurses experience (0.231).

Table (6): Shows the correlation between staff nurses' performance level and their level of occupational stress at Belkas Central Hospital. It illustrated that $82.5 \%$ of staff nurses who had satisfactory performance, had high level of stress, and also all nurses who had unsatisfactory performance level had high level of stress. Also there are no statistically significant correlation between staff nurses' performance level and their level of occupational stress $(0.133)$. 
Table (1): Staff nurses level of occupational stress at Belkas Central Hospital ( $\mathrm{n}=$ 131)

\begin{tabular}{|c|c|c|c|c|c|c|c|c|}
\hline \multicolumn{8}{|c|}{ Level of occupational stress } & \multirow{3}{*}{ Stressors } \\
\hline \multicolumn{2}{|c|}{$\begin{array}{c}\text { Low } \\
(<33.3 \%)\end{array}$} & \multicolumn{2}{|c|}{$\begin{array}{c}\text { Moderate } \\
\text { (33.3- } \\
<66.7 \%)\end{array}$} & \multicolumn{2}{|c|}{$\begin{array}{c}\text { High } \\
(66.7 \% \leq)\end{array}$} & \multirow[t]{2}{*}{ Mean \pm SD } & \multirow[t]{2}{*}{ Min-Max } & \\
\hline$\%$ & No. & $\%$ & No. & $\%$ & No. & & & \\
\hline 0.0 & 0 & 28.2 & 37 & 71.8 & 94 & $73.3 \pm 9.6$ & $40.0-97.6$ & Work stressors \\
\hline 0.0 & 0 & 22.1 & 29 & 77.9 & 102 & $74.0 \pm 13.9$ & $42.9-100.0$ & Task stressors \\
\hline 2.3 & 3 & 26.0 & 34 & 71.8 & 94 & $70.8 \pm 15.5$ & $33.3-100.0$ & Patients stressors \\
\hline 0.0 & 0 & 12.2 & 16 & 87.8 & 115 & $79.9 \pm 13.9$ & $47.6-100.0$ & Physician stressors \\
\hline 0.0 & 0 & 20.6 & 27 & 79.4 & 104 & $77.1 \pm 15.5$ & $45.5-100.0$ & $\begin{array}{l}\text { Human and } \\
\text { physical stressors }\end{array}$ \\
\hline 0.0 & 0 & 7.6 & 10 & 93.1 & 122 & $84.8 \pm 11.2$ & $55.6-100.0$ & $\begin{array}{l}\text { Educational and } \\
\text { vocational stressors }\end{array}$ \\
\hline 0.0 & 0 & 16.0 & 21 & 84.0 & 110 & $76.9 \pm 10.2$ & $52.6-94.9$ & Total score \\
\hline
\end{tabular}

Table (2): Staff nurses performance at Belkas Central Hospital $(n=131)$

\begin{tabular}{|c|c|c|c|c|c|c|}
\hline \multicolumn{6}{|c|}{ Performance level } & \multirow{3}{*}{$\begin{array}{c}\text { Staff nurses } \\
\text { performance items }\end{array}$} \\
\hline \multicolumn{2}{|c|}{ Satisfactory } & \multicolumn{2}{|c|}{ Unsatisfactory } & \multirow{2}{*}{ Mean \pm SD } & \multirow{2}{*}{ Min-Max } & \\
\hline$\%$ & No. & $\%$ & No. & & & \\
\hline 75.6 & 99 & 24.4 & 32 & $81.2 \pm 24.3$ & $30.0-100.0$ & $\begin{array}{l}\text { Assessment of patient } \\
\text { status }\end{array}$ \\
\hline 97.7 & 128 & 2.3 & 3 & $85.4 \pm 9.1$ & $60.7-100.0$ & General patient care \\
\hline 89.3 & 117 & 10.7 & 14 & $85.6 \pm 15.2$ & $31.3-100.0$ & Communication \\
\hline 42.7 & 56 & 57.3 & 75 & $62.2 \pm 17.7$ & $22.7-95.8$ & $\begin{array}{l}\text { Patients' psychosocial } \\
\text { aspects }\end{array}$ \\
\hline 95.4 & 125 & 4.6 & 6 & $78.8 \pm 9.1$ & $40.0-100.0$ & Professionalism \\
\hline 91.6 & 120 & 8.4 & 11 & $78.5 \pm 9.6$ & $46.9-95.1$ & Total \\
\hline
\end{tabular}


Table (3): Correlation between staff nurses stressors and their performance score at Belkas Central Hospital $(\mathrm{n}=131)$

\begin{tabular}{|c|c|l|}
\hline \multicolumn{2}{|c|}{ Performance score } & \multicolumn{2}{|}{ Stressors items } \\
\hline P & $\mathbf{R}$ & \\
\hline $0.013^{*}$ & -0.307 & Work stressors \\
& -0.232 & Task stressors \\
\hline $0.002 *$ & -0.396 & Patients stressors \\
\hline $0.041^{*}$ & 0.217 & Physician stressors \\
\hline 0.098 & -0.207 & Human and physical resources stressors \\
\hline $0.008^{*}$ & -0.336 & Educational and vocational stressors \\
\hline $0.0133^{*}$ & -0.305 & Total score \\
\hline
\end{tabular}


Table (4): Relationship between of staff nurses' occupational stress level and their demographic characteristics at Belkas Central Hospital $(n=131)$

\begin{tabular}{|c|c|c|c|c|c|}
\hline \multirow{3}{*}{ Significance } & \multicolumn{4}{|c|}{ Staff nurses occupational stress level } & \multirow{3}{*}{ Socio-demographic characteristics } \\
\hline & \multicolumn{2}{|c|}{$\begin{array}{c}\text { High } \\
{[\mathrm{n}=110]}\end{array}$} & \multicolumn{2}{|c|}{ Moderate [n=21] } & \\
\hline & $\%$ & No. & $\%$ & No. & \\
\hline \multirow{3}{*}{$0.041^{*}$} & & & & & Age \\
\hline & 78.2 & 86 & 95.2 & 20 & $20-$ \\
\hline & 9.1 & 10 & 4.8 & 1 & $30-$ \\
\hline \multirow{4}{*}{$0.003^{*}$} & 12.7 & 14 & 0.0 & 0 & $\begin{array}{l}40 \text { or more } \\
\text { Marital status }\end{array}$ \\
\hline & 20.9 & 23 & 14.3 & 3 & Single \\
\hline & 79.1 & 87 & 38.1 & 8 & Married \\
\hline & 0.0 & 0 & 47.6 & 10 & Widow/divorced \\
\hline \multirow{4}{*}{$0.012^{*}$} & & & & & Number of children \\
\hline & 49.1 & 54 & 9.5 & 2 & No children \\
\hline & 48.2 & 53 & 14.3 & 3 & $1-2$ \\
\hline & 2.7 & 3 & 76.2 & 16 & $3-4$ \\
\hline \multirow{3}{*}{$0.005^{*}$} & 33.6 & 37 & 42.9 & 9 & $\begin{array}{l}\text { Educational level } \\
\text { Nursing technical school diploma }\end{array}$ \\
\hline & 2.7 & 3 & 47.6 & 10 & Nursing technical institute diploma \\
\hline & 63.6 & 70 & 9.5 & 2 & Nursing faculty \\
\hline \multirow{5}{*}{0.098} & & & & & Department \\
\hline & 27.3 & 30 & 19.0 & 4 & Dialysis unit \\
\hline & 20.0 & 22 & 38.1 & 8 & Neonates unit \\
\hline & 20.0 & 22 & 19.0 & 4 & Intensive care unit \\
\hline & 29.1 & 32 & 42.9 & 9 & Emergency unit \\
\hline \multirow{4}{*}{0.110} & & & & & Years of experience \\
\hline & 58.2 & 64 & 47.6 & 10 & Less than 5 \\
\hline & 18.2 & 20 & 47.6 & 10 & $5-$ \\
\hline & 23.6 & 26 & 4.8 & 1 & 10 or more \\
\hline
\end{tabular}


Table (5): Relationship between staff nurses performance level and their demographic characteristics at Belkas Central Hospital ( $\mathrm{N}=131)$.

\begin{tabular}{|c|c|c|c|c|c|}
\hline \multirow{3}{*}{ Significance } & \multicolumn{4}{|c|}{ Staff nurses performance level } & \multirow{3}{*}{$\begin{array}{l}\text { Socio-demographic } \\
\text { characteristics }\end{array}$} \\
\hline & \multicolumn{2}{|c|}{$\begin{array}{c}\text { Satisfactory } \\
\text { (65\% or more) } \\
{[n=120]}\end{array}$} & \multicolumn{2}{|c|}{$\begin{array}{c}\text { Unsatisfactory } \\
\text { (Less than } \\
65 \%) \\
{[n=11]}\end{array}$} & \\
\hline & $\%$ & No. & $\%$ & No. & \\
\hline \multirow{4}{*}{$0.041^{*}$} & & & & & Age \\
\hline & 79.17 & 95 & 100.00 & 11 & $20-$ \\
\hline & 9.17 & 11 & 0.00 & 0 & $30-$ \\
\hline & 11.67 & 14 & 0.00 & 0 & 40 or more \\
\hline \multirow{3}{*}{$0.001^{*}$} & & & & & Marital status \\
\hline & 21.67 & 26 & 0.00 & 0 & Single \\
\hline & 78.33 & 94 & 9.09 & 1 & Married \\
\hline \multirow{4}{*}{0.082} & 0.00 & 0 & 90.91 & 10 & $\begin{array}{l}\text { Widow/divorced } \\
\text { Number of children }\end{array}$ \\
\hline & 40.83 & 49 & 63.64 & 7 & No children \\
\hline & 43.33 & 52 & 36.36 & 4 & $1-2$ \\
\hline & 15.83 & 19 & 0.00 & 0 & $3-4$ \\
\hline \multirow{3}{*}{$0.021 *$} & & & & & Educational level \\
\hline & $\begin{array}{l}35.83 \\
6.67\end{array}$ & 43 & $\begin{array}{l}27.27 \\
45.45\end{array}$ & 3 & $\begin{array}{l}\text { Nursing Technical School } \\
\text { Diploma Degree } \\
\text { Nursing Technical Institute } \\
\text { Diploma Degree }\end{array}$ \\
\hline & 57.50 & 69 & 27.27 & 3 & Bachelor Degree \\
\hline \multirow{5}{*}{$0.001 *$} & & & & & Department \\
\hline & 28.33 & 34 & 0.00 & 0 & Dialysis unit \\
\hline & 25.00 & 30 & 0.00 & 0 & Neonates unit \\
\hline & 21.67 & 26 & 0.00 & 0 & Intensive care unit \\
\hline & 25.00 & 30 & 100.00 & 11 & Emergency unit \\
\hline \multirow{3}{*}{0.231} & 55.00 & 66 & 72.73 & 8 & $\begin{array}{l}\text { years of experience } \\
\text { Less than } 5\end{array}$ \\
\hline & 22.50 & 27 & 27.27 & 3 & $5-$ \\
\hline & 22.50 & 27 & 0.00 & 0 & $10-$ \\
\hline
\end{tabular}


Table (6): Correlation between staff nurses performance level and their level of occupational stress at Belkas Central Hospital (N=131)

\begin{tabular}{|c|c|c|c|c|c|}
\hline \multirow{3}{*}{ Significance } & \multicolumn{4}{|c|}{ Performance level } & \multirow{3}{*}{ Stress level } \\
\hline & \multicolumn{2}{|c|}{$\begin{array}{c}\text { Unsatisfactory } \\
\text { (Less than } \\
65 \%) \\
{[n=11]}\end{array}$} & \multicolumn{2}{|c|}{$\begin{array}{c}\text { Satisfactory } \\
\text { (65\% or more) } \\
{[n=120]}\end{array}$} & \\
\hline & $\%$ & No. & $\%$ & No. & \\
\hline \multirow{3}{*}{0.133} & 0.00 & 0 & 17.50 & 21 & Moderate \\
\hline & 100.00 & 11 & 82.50 & 99 & High \\
\hline & 0 & 0 & 0 & 0 & low \\
\hline
\end{tabular}

\section{DISCUSSION:}

The consequences of stress are multi-faceted. It affected the nurses and the organization (Annamalia, 2014). Support of supervisor, relations and collaboration in decision making are characteristics which help the nurse to be independent and able to provide services in a stressful environment which would help in improving their performance (Najimi et al., 2012).

The findings of the present study revealed that the greatest percentage of staff nurses had high occupational stress level. This result may be because the nurse is the first person that the client usually comes in contact within any hospital setting. They were usually faced the most severe emotional situations as well as continuously meet the demands of patients and their relatives. Therefore, they are confronted with the heavy workload which is one of the most important factors influencing their stress level. This findings agreed with Ismail et al., (2015) who found that, occupational stress is common in nurses and has important consequences for individual nurses, patient care, and the health service as a whole. On contrary, this result of the present study were not consistent with Najimi et al., (2012) whose found that, nurse's had moderate level of occupational stress.

The present study denoted that educational and vocational stressors represent the highest area of stress that may be due to lack of acknowledgement of the nursing profession and feeling that there is difference between educational preparation and the reality of the work. This result was supported by Viljoen and Rothmann (2009) who 
reported that, nurses had high occupational stress level with educational and vocational stressors.

The present study was concluded that staff nurses had high stress level with physician stressors which considered as the second area of high stress level for staff nurses due to insufficient number of doctors and lack of physician realization of the importance of nurses' role with no trust in the nurses knowledge and practice. This finding comes in line with Mrayyan (2009) who concluded that, conflict with physicians and lack of social support represents the main sources of stress for staff nurses. Also, Sharma et al. (2014) whose found that, the main nurses' occupational stressors were poor doctor's attitude at emergency and intensive care units. This result goes relatively with Konstantinos \& Christina (2008) whose reported that, nurses whose have low levels of stress will have collaborative relationships with doctors.

The present study was revealed that the greatest percentage of staff nurses at Belkas Central Hospital had satisfactory level of performance. This is may be due to the presence of academic staff, internal training programs conducted by quality and infection control hospital teams and external training programs that help staff nurses to refresh their knowledge and acquire new skills that help in improving their performance. This area of discussion of the present study was supported by Gilbert et al. (2014) whose found that, the performance ratings of nurses by their managers, had satisfactory level. In the same line, Qteat $\&$ Sayej (2014) whose concluded that nurse's performance was good.

This finding was not consistent with, Kamal (2014) who found that, the performance evaluation among the studied nurses working in intensive care unit was relatively low. Also, Al- Homayan et al. (2013) whose conduct a study on nurses in public sector hospitals in Saudi Arabia stated that, nurses had moderate performance level.

The present study illustrated that staff nurses had the highest total mean score of performance in general patient care because this study was conducted at intensive care units, in which nurses usually deals with dependent patients who receive all care from nurses only that they need intensive and accurate care with safe and comfortable environment. This findings agreed with Ahmed et al. (2015) whose reported that, nurses had good performance level in general patient care. While, this study finding contradicted with Abdrabou (2002) who reported in his study of relationship between 
nurses' job satisfaction and quality of their performance that, nurses didn't meet patient physical needs as expected from them.

The present study revealed that staff nurses had unsatisfactory score of performance with patient's psychosocial aspects because the studied staff nurses had high stress level and psychologically disturbed which make them unable to provide patients with psychological support. This finding agreed with Abdou (2009) who found that, staff nurses' performance was unacceptable in patients' psychosocial aspects.

The findings of the present study illustrated that there were no statistically significant correlation between staff nurse's total performance and their total stressors at Belkas Central Hospital. This situation can be interpreted as employees want to perform well because of their need of money, fear from punishment and money loss, or because they want a promotion which makes them didn't let other circumstances such as stress interfering that. Also, they working at units that considered as live saving departments in which any defect may lead to death of patients that made staff nurses do their best so as to save patients' life, although they were under high level of stress.

This finding agreed with Gilbert et al. (2014) who found that, job stress do not impact registered nurses job performance. Also in the line with, World Health Organization (2005) in the study of mental health and working life that, no statistically significant relation between performance and stress level. This findings were not consistent with Lutfi \& Moh'd (2012) whose found in their study of the relationship between job stress and nurses performance in the Jordanian Hospitals that, the stress caused by the difficult nature of nursing job is positively associated with both nurses creativity and innovation and their ability in problem solving and decision making.

\section{CONCLUSION:}

In the light of the study findings, it can be concluded that although most of staff nurses had high level of occupational stress, they also had satisfactory score of performance but generally; there were no statistically significant relationship between staff nurses' performance level and their occupational stress level at Belkas Central Hospital. 


\section{Recommendations:}

Based on the findings of the current study, the following recommendations are suggested:

- Clarify hospital mission, vision, policies, rules, regulations and job description for nurses.

- Provide the staff nurses with training programs to improve their performance and their ability to cope with stress.

- Provide the unit with adequate number of staff nurses, workers and coworkers.

- Managing stress through staff nurses participation in decision making, controlling interruptions (e.g. visitors, telephone) and organizing work environment.

- Nursing managers have a role in improving nursing image and protecting nursing rights.

\section{REFERENCES:}

Abdelrazek F. (2000) : Study of Absenteeism and Factors Contributing to It . Unpublished Master Thesis. Faculty of nursing, Sues Canal University, Egypt.

Abdou H. (2009): Relationship between Nurses' Job Satisfaction and Quality of their Performance in Abu-Kabier General Hospital. Unpublished Master Theses. Faculty of Nursing, Zagazig University, Egypt.

Abdrabou F. (2002): Relationship between Nurses' Job satisfaction and Quality of their Performance. Unpublished Master Thesis, Faculty of Nursing, Ain Shams University, Egypt.

Abu Al Rub R. and Al-Zara I. (2008): Job stress, recognition, job performance and intention to stay at work among Jordanian Hospital nurses. Journal of Nursing Management; 16 (3): 227-36. 
Ahmed M., Sleem W. and Kassem A. (2015): Effect of working condition and fatigue on performance of staff nurses at El-Mansoura University Hospital. Nursing Administration Department, Faculty of Nursing, El-Mansoura University, Journal of Nursing and Health Science 4 (3): 83-91. Available at: www.iosrjournals.org.

Al-Homayan A., Shamsudin F., Subramaniam C. and Islam R. (2013): Impacts of job performance level on nurses in public sector hospitals. American Journal of Applied Science. 10 (9):1115- 23.

Annamalai S. (2014): Occupational Stress: A Study of Employee Stress in Indian. Ides. Ind. 49:50. Available at: http:googlebooks.com.

Awases M. (2006): Factors Affecting Performance of professional Nurses in Namibia. University of South Africa, Published Doctoral Thesis, 250- 1, available at: https://www.researchgate.net.

Charles R. (2006): Umiker's Management Skills for the New Health Care Supervisor. $4^{\text {th }}$ ed. Ontario, 203- 4. Available at: www.jblearning.com.

Clark P., Leddy K., Drain M. and Kaldenberg D. (2007): State shortages and patient satisfaction: More registered nurses - better patient experiences. Journal of Nursing Care Quality, 22 (2): 119- 27.

Gilbert M., Tiriyo I., Ritacco G. and Lowies A (2014): Impact of occupational stress and burnout on employee job performance: a study of nurses in rural clinics of Bushbuckridge in Mpumalanga Province. International Journal of Innovative Research in Management; (1): 2319 - 22.

Haussaman R. (1997): Monitoring Quality of Nursing Care. Journal of Nursing Research, 41 (5): 280- 5.

Holmes T. and Rahe' R. (1967): The Social Readjustment Rating Scale. Journal of psychosomatic Research, 11 (2): 73-75. 
Ismail A, Saudin N, IsmailY, Abu Samah AAbu Bakar R, Aminudin N (2015):

Effect Of Workplace Stress On Job Performance. Economic Review - Journal of Economics and Business, Vol. XIII, Issue 1.

Ivancevich J. (2003): Human Resource Management. $9^{\text {th }}$ ed., McGraw Higher Education, New York, 560- 1. Available at: http://www.alibris.com/

Kamal N. (2014): Relationship between Head Nurses' Leadership Styles and Staff nurses' Job Performance. Unpublished Master Thesis, Faculty of Nursing, Port Said University, Egypt.

Kaur S. (2009): Stress and coping in nursing student. Journal of Mental Health and Human Behavior; 14 (1): 51- 6. Available at: www.ipsnz.org

Konstantinos N. and Christina O. (2008): Factors influencing stress and job satisfaction of nurses working in psychiatric units. Health Science Journal; 2 (2): 183 95.

Lutfi A. and Moh'd S. (2012): The relationship between job stress and nurses performance in the Jordanian Hospitals. Asian Journal of Business Management 5 (2): 267- 75 .

Milutinovic D., Golubović B., Brkić N. and Prokeš B. (2012): Professional stress and health among critical care nurses in Serbia. Arch. Ind. Hyg. Toxicol., 63 (2): 17180.

Mrayyan, M. (2009): Job stressors and social support behaviors: Comparing intensive care units to wards in Jordanian. Contemporary Nurses, 31 (2): 163- 75.

Najimi A., Moazemi A., and Sharifirad G. (2012): Causes of job stress in nurses: A cross-sectional study. Iranian Journal of Nursing and Midwifery Research._17 (4): $301-05$.

Qteat M. and Sayej S. (2014): Factors affecting time management and nurses' performance in Hebron Hospitals. Journal of Education and Practice. 5 (35): 41-59. 
Richard A. (2006): Perceived stressors, coping strategies, and burnout pertaining to psychiatric nurses working on locked psychiatric units. Available at: http://commons.emich.edu/theses

Said M. (2000): Nursing Management of Patients with Total Hip Replacement at Orthopedic Wards in Selection Hospital. Unpublished Master Thesis. Faculty of Nursing, Ain Shams University, Egypt.

Sansgiry S. (2006): Factors that affect academic performance among pharmacy students. American Journal of Pharmaceutical Education; 70 (5): 104.

Sharma P., Davey A., Sanjeev Davey S., Shukla A., Kajal Shrivastava K. and Bansal R. (2014): Occupational stress among staff nurses: controlling the risk to health, Indian Journal of Occup Environ Med.18 (2):52-6.

R. (2014): Occupational stress among staff nurses: controlling the risk to health, Indian Journal of Occup Environ Med. 18 (2): 52- 6.

Ugur S. Acuner M. Göktaş B. and Senoğlu B. (2007): Effects of physical environment on the stress levels of hemodialysis nurses in Ankara Turkey. J. Med. Syst., 31 (1): 283- 87.

Viljoen J and Rothmann S. (2009): Occupational stress, ill health and organizational commitment of employees at a university of technology. SA j. ind. Psychol. vol.35 n.1

Walshe K. and Smith J. (2011): Health Care Management; $2^{\text {nd }}$ ed. UK Bell and Bain Ltd, Glasgow,516- 20.

World Health Organization, WHO. (2005): Mental Health and Working Life. Available at: 6www.Euro.who.int/document/mnh/ebriefo6.pdf. 


\section{الضغط المهني ومستوى أداء الممرضين بمستثفى بلقاس المركزي.}

أ.م.د / صفاء عبد المنعم توفيق زهران ، د/ عبير السيد محمد برمه ، كريمه عبد السيد محمد أبو العنين

استاذ مساعد ادرة التمريض كلية التصريض جامعة طنطا ، مدرس التصريض النفسى والصحة العقلية كلية

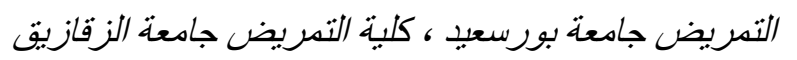

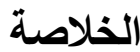

الدراسة الحالية دراسة وصفية هدفها تقييم العلاقة بين الضغط المهني ومستوى أداء الممرضين/ الممرضات بمستشفى بلقاس المركزي التابعة لوزارة الصحة. وقد أجريت هذه الدراسة بأقسام الرعاية

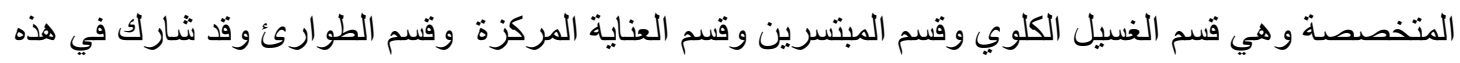
الدراسة عدد مائه و أحدي وثلاثون ممرض وممرضه. استخدمت هذه الدر اسة نو عين من الاستبيان: الاداه الأولي

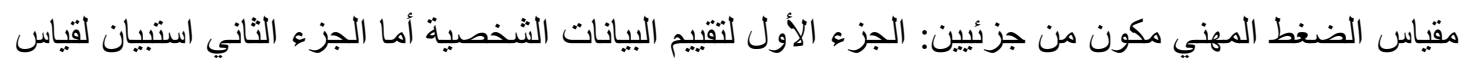
الضغط المهني. الاداه الثانية قائمة الملاحظة لقياس مستوى أداء التمريض. وقد أظهرت نتائج الدراسة بأنه علي

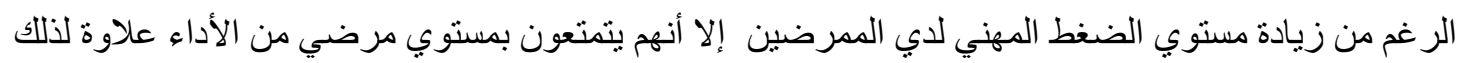

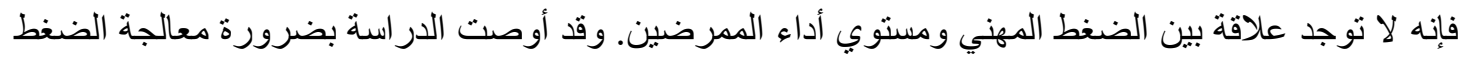
المهني من خلال مشاركة الممرضين في اتخاذ القرارات، التحكم في التنخلات أثناء العمل (مثل الزيارة و التليفون)، وتنظيم بيئة العمل و عمل دورات تدرييية للتمريض لمساعدتهم علي التعامل مع ضغوط العمل لتحسين أدائهم. 